\title{
Determinants of Office Space Choice
}

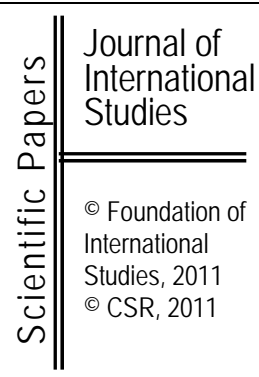

PhD Krzysztof Celka

Department of Investment and Real Estate

Faculty of Management

Poznan University of Economics

kryysztof.celka@ue.poznan.pl

\begin{abstract}
This paper presents the main results of the study on preferences of tenants active on the office property market in Poznań. The study was carried out at the turn of 2011 and was triggered by the situation on the office property market in Poznan and imbalance in the supply-demand relation. The aim of the study was to identify demand-related factors determining the selection of an office by tenants.
\end{abstract}

Submitted:, October, 2011 1st revision: September, 2011 Accepted: November, 2011

Keywords: property, office, demand, preferences, Poland

JEL classification: E32, R33, P2.

\section{Introduction}

Commercial properties represent a significant share in the total volume of properties. This market varies in many aspects from other capital or commodity market segments which are well-known and have been already analysed in detail (Gawron, 2011, p. 8). The change of the economic system triggered major changes in almost every area of the property management system in place at that time. The competitive market economy brought in the establishment of new entities, change of approach and behaviour of potential customers as well as rapid development of commercial office space.

The property market is a market characterised by the transfer of rights to properties (Kucharska-Stasiak, 2006, p. 7). The market can be classified based on various criteria. Applying a criterion of property type, one can identify, among others, the commercial property market. A commercial property is a property used for conducting business activity (Dolf de Roos, 2008, p. 2). A commonly applied classification of commercial property market differentiates between the lease market and investment market (Załęczna, 2010, p. 81). Disaggregation of the commercial market allows the researchers to identify the office property market. This market also comprises the lease of office space. The office space market, defined as a local lease market, varies depending on the urban area. Every urban area is characterised by a specific spatial structure shaped by numerous transformations occurring in the long-term development process (Jaroszewska, Stryjakiewicz, 2009, p.11).

\section{Poznań - a place for conducting business operations}

Poznań is a peculiar office space market which for a few years has been attracting more and more investors. In the last decade, the market saw strong differences between 
demand and supply which is typical for a maturing market. In the period of global economic slowdown, the foreign investors' interest in the market has diminished, yet still a significant element of demand for office space is the development of the BPO sector (service centres). At present, in Poznań, there are almost 30 such centres employing almost 6k people. Poznań has been developing dynamically - the potential is rooted mainly in the Poznan agglomeration which is a developing power for the city. Alarming demographic data referring to an ongoing outflow of the citizens are offset by a dynamic economic growth of the peripheral municipalities. If we take a wider look at Poznan, we will see that the office space market has still a great potential to grow $-551 \mathrm{k}$ citizens of the city plus $315 \mathrm{k}$ inhabitants of the poviat area make up a robust social $\&$ economic centre. The potential is additionally enhanced by the role of Poznań as a business centre with 98k business entities and as an academic centre with ca. 140k students residing in the city. Nevertheless, supply of modern office space is relatively lower as compared to other urban areas of similar size in Poland.

\section{Introduction to the study of tenant preferences}

To illustrate the situation, one has to define modern office space in Poznań. There are various markets using classification of office space based on different determinants, such as e.g. location, standard, etc., rated as A, B, C class units. Frequently, when referring to the office space market, business areas are specified which allow for assigning buildings to particular classes based on a certain criterion, e.g. location. In such a case, location is considered the most important criterion for building classification.

On the basis of the studies carried out for some years by the author of this paper on the office space market in Poznań, it can be concluded that the above classification of buildings is of no significant importance in Poznań (Celka, 2010).

Firstly, in Poznań there is no explicitly specified central business area. In large urban areas, a central business area is advantaged in terms of the location - small area is occupied by many entities conducting the same or similar business operations (Budner, 2004, p.104). An office property should be located in the central business area or in the developed outskirts of the city (Kyle, Baird, Spodek, 2000, p. 6).

In Poznań, such an area has not been developed. Modern office units in Poznań are dispersed all around the city and it is difficult to identify an office space concentration zone. The majority of office units are located around the historical centre of Poznan (the Stare Miasto district). Many buildings are also located in the Grunwald and Winogrady districts. It is assumed that the buildings located around the Stary Browar shopping centre could be regarded as such an area, yet the supply of space there would have to be much higher than currently. Apart from the office space in the Stary Browar shopping centre, only two office buildings are located there. In general, office space can be broken down into space located inand outside the city centre.

Secondly, office buildings which were constructed in the last 10 years do not differ significantly in terms of their standard parameters. Most of them are equipped with similar technical and functional elements.

Office space in Poznań can be basically classified into modern and non-modern office space. The study on modern office space supply shows that there is ca. $200 \mathrm{k} \mathrm{m} 2$ of usable space in Poznań. The analysed office buildings house around 2,000 businesses. The remaining several tens of thousands of businesses are located in the buildings described by the author of the study as non-modern office space comprising C- or D-class buildings (according to the abovementioned classification) as well as tenement houses located all around Poznań. Supply of such non-modern office space amounts to ca. 600k m2. In total, office space in Poznań stands at ca. 800k m2 (Celka, 2010). 
To explain why the modern office space in Poznań is so limited (as compared to other cities), one has to analyse the tenants of such space in Poznań and their structure.

It is said that Poznan is a city of small and medium-sized businesses. The statistical data published by the Central Statistical Office (GUS) confirm that. As already mentioned, over 98k businesses are registered in Poznań and a clear majority of them represent the private sector. Almost $3 / 4$ of them are sole traders. Average employment rate amounts to over $144 \mathrm{k}$, which translates into 1.5 employee per business on average.

The studies on the demand for office space in Poznań conducted by the author provide the answer to the question concerning tenant preferences. Office space is considered attractive if its location provides good possibilities of selling information or services.

Modern office space is often a subject of various studies. It has been proved, however, that non-modern office space (frequently not taken into account in studies) represent a significant part of the office space in Poznan crucial to the operations of the entire office property market. The study was conducted at the turn of 2011 and concerned the preferences of tenants leasing such office space in Poznań. 152 entities were analysed. The businesses analysed in the study were selected purposefully. The basic criterion was the size of the business (companies employing up to 10 people) and leased space (i.e. small tenants leasing up to $200 \mathrm{~m} 2$ ). The study was conducted in 4 Poznań districts (Centrum, Wilda, Grunwald, Nowe Miasto) - 38 businesses in each of them were analysed.

Respondents were asked to answer eight questions. The first one regarded the impact of indicated determinants on the location of the office. In the second question, tenants were asked to order the six determinants assessed by them as the most significant ones according to their importance. The next few questions referred to the size of the leased office, number of employees, intention to change the office location, possible improvements in the building as well as indication of the sector the company operates in. The last question concerned the attractiveness of the office building location.

\section{Tenants preferences on the office space market}

The analysis focused on aggregated preference determinants presented in the table below. Each criterion comprised seven specific determinants. Respondents were asked to evaluate 49 factors. The evaluation scale ranged from 1 (unimportant) to 5 (important).

Table 1. Classification of office selection criteria used by tenants

\begin{tabular}{|c|c|}
\hline \multicolumn{2}{|r|}{ Factors } \\
\hline \multirow[t]{7}{*}{ Location } & safe neighbourhood \\
\hline & commercial centres accessibility \\
\hline & small distance from business partners \\
\hline & building visibility \\
\hline & low level of noise and air pollution \\
\hline & window view \\
\hline & location prestige \\
\hline \multirow{6}{*}{$\begin{array}{l}\text { Lease terms } \\
\text { and conditions }\end{array}$} & parking place cost \\
\hline & number of parking places assigned to specific leased space \\
\hline & shared area charges \\
\hline & maintenance costs \\
\hline & owner's expenditure incurred for office space fit-out \\
\hline & maintenance costs elements (maintenance costs list) \\
\hline
\end{tabular}




\begin{tabular}{|c|c|}
\hline & rent \\
\hline \multirow[t]{7}{*}{ Accessibility } & access to train and bus stations \\
\hline & access to airport \\
\hline & access to public administration offices \\
\hline & access to the building with public means of transport \\
\hline & $\begin{array}{l}\text { access to the building by personal means of transport (private or } \\
\text { company cars) }\end{array}$ \\
\hline & access to roads leading to and from Poznań / access to motorway \\
\hline & distance from the home of the boss \\
\hline \multirow{7}{*}{$\begin{array}{c}\text { Building } \\
\text { characteristics }\end{array}$} & building size (scale) \\
\hline & office units size \\
\hline & building aesthetics (nice elevation, new windows, etc.) \\
\hline & building function uniformity (e.g. only office building) \\
\hline & possibility of arranging space tailored to own needs \\
\hline & typical floor layout \\
\hline & building design (architecture) \\
\hline \multirow{7}{*}{$\begin{array}{l}\text { Building } \\
\text { features }\end{array}$} & reception area \\
\hline & server room \\
\hline & $\begin{array}{l}\text { other services (e.g. bar, restaurant, flower shop, newsagents, bank, } \\
\text { medical services, etc.) }\end{array}$ \\
\hline & elevator (or elevators) \\
\hline & utility room availability (e.g. for archiving purposes) \\
\hline & rest and refreshment room availability (kitchenette) \\
\hline & conference room(-s) availability \\
\hline \multirow[t]{7}{*}{ Fit-out } & installations (Internet, phone lines, etc.) \\
\hline & room height \\
\hline & tilt windows \\
\hline & furnished rooms \\
\hline & suspended ceiling \\
\hline & interior arrangement flexibility \\
\hline & air-conditioning \\
\hline \multirow[t]{7}{*}{ Ad-on factors } & vicinity of recreation centres (fitness) \\
\hline & vicinity aesthetics \\
\hline & office area lighting \\
\hline & developer brand / tenant image \\
\hline & customer parking places \\
\hline & building security \\
\hline & noise level in offices - walls and doors soundproofing \\
\hline
\end{tabular}

Source: own study

The studies show that the most important criterion used when selecting an office are the lease terms and conditions (1/3). 


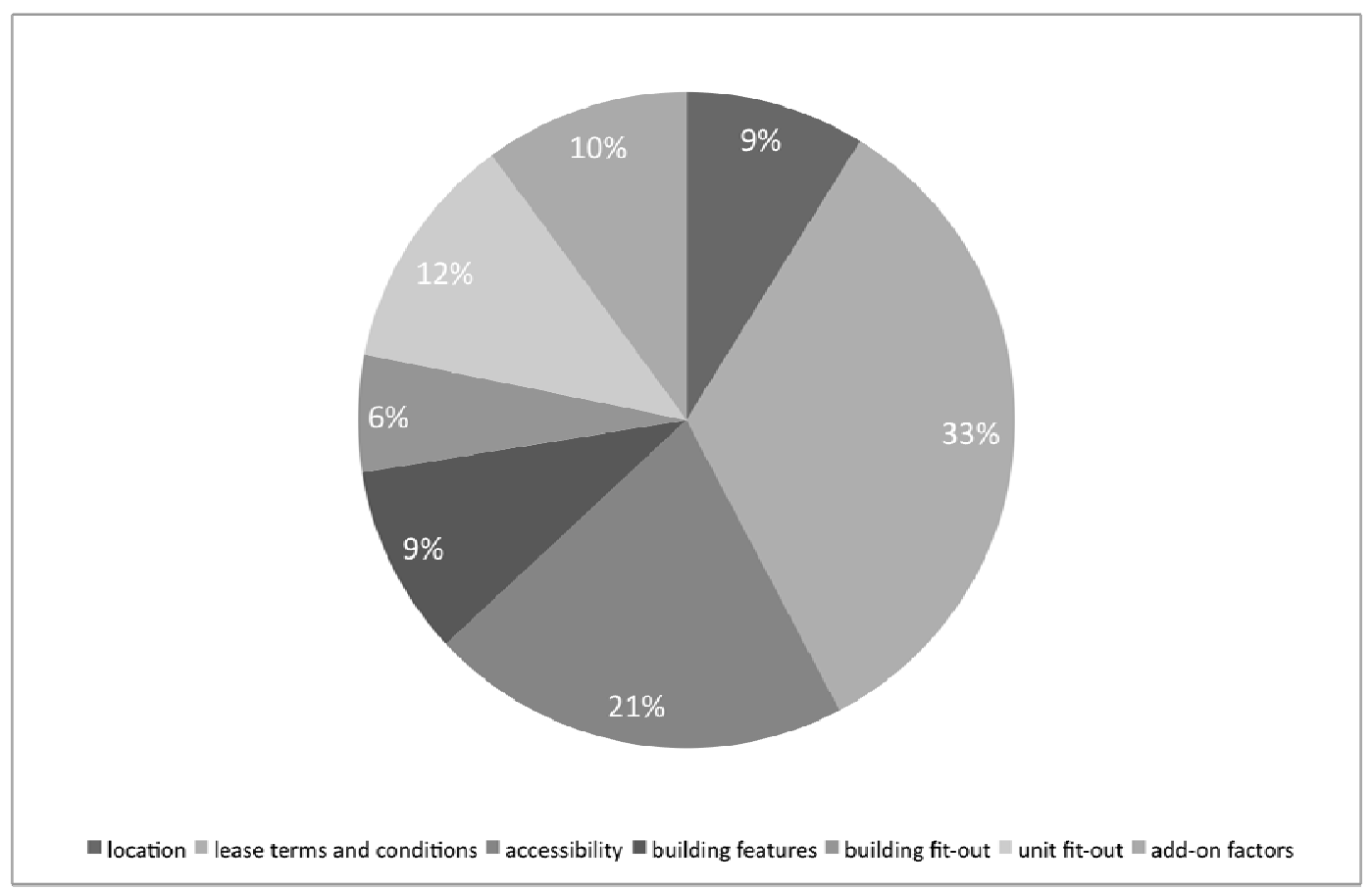

Fig 1. Importance of office selection criteria used by tenants Source: own study

This criterion comprises seven elements (rent, maintenance costs, number of parking places assigned to the office space, parking place cost, maintenance costs elements, owner's expenditure incurred for office space fit-out, shared areas charges). The chart below presents the significance of the elements.

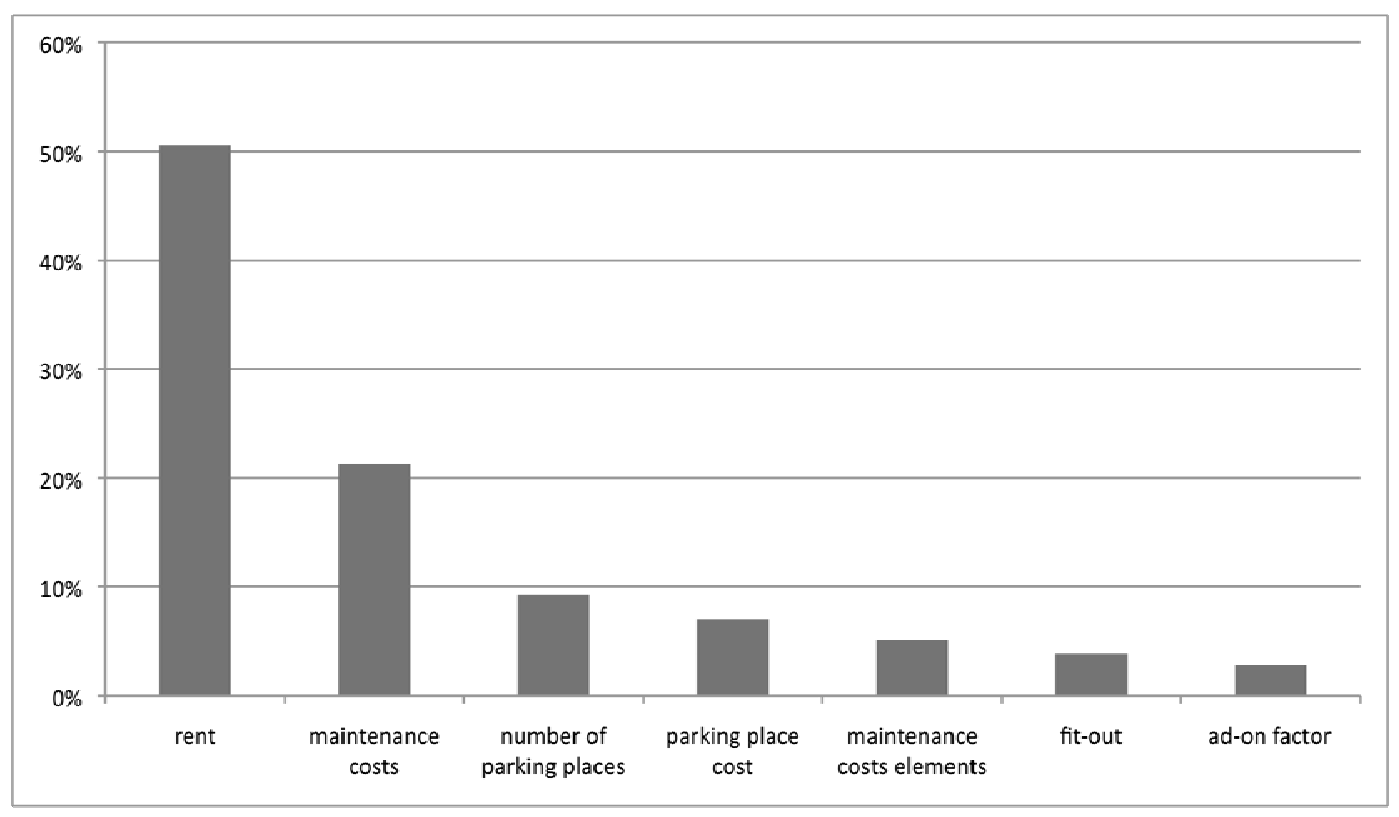

Fig 2. Importance of elements related to lease terms and conditions Source: own study

It turns out that at the time of the global economic crisis the most important factor considered when selecting office space is not the location but the rent, followed by 
maintenance costs. Both criteria are most important for nearly $2 / 3$ of tenants. Location was indicated an important factor by more than $1 / 5$ of respondents.

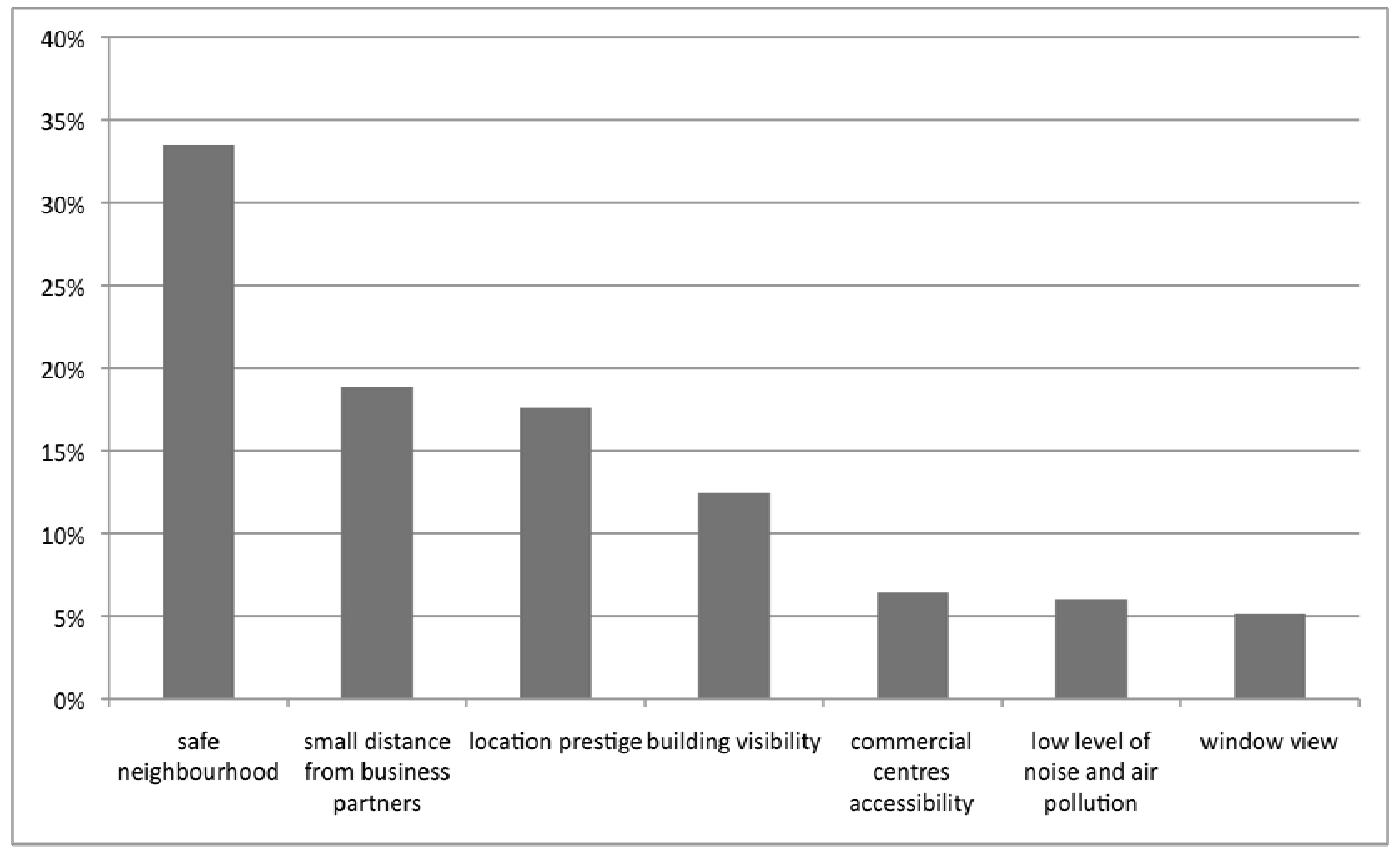

Fig. 3. Importance of factors related to location

Source: own study

The next important factor is accessibility. It comes as no surprise that office accessibility both with public means of transport and by cars is the most important factor (the office accessibility by the company's owner/boss should be noted here). As many as $13 \%$ of the respondents claim that this is a very important factor for them. It should be emphasised that considering the on-going preparations for Euro2012, the city is one large infrastructure building site, resulting in transport problems, which might have influenced the answers. Nevertheless, it turns out that apart from the rent or location, also a very subjective factor, i.e. office accessibility by the boss, might be of high importance for companies when selecting office space.

The biggest challenge for the Poznan market these days will be maintaining the balance between supply and demand. Dangerously high vacancy level in the existing projects $(16 \%)$ must raise questions concerning the future of the market. One of the elements that could offset the above might be intensive works carried out as part of infrastructural projects. As a result of the preparations for EURO2012 Poznań will pride itself on investments such as: Zintegrowane Centrum Komunikacyjne (Integrated Transportation Center), double capacity of Lawica airport combined with modern transportation set-up, completion of works at A2 motorway and city ring roads. The investments' scale and type will positively impact the growth of the local economy and strengthen the basis of the urban area integration.

Investors' confidence in the Poznań market might be threatened by difficult economic situation on both European and global markets. Insufficient annual absorption on the office space market would be very dangerous for the growth prospects of the development business in the upcoming years. Reaching sustainable market vacancy rate (ca. 10\%) will be thus be the most important test for the city growth prospects. 


\section{Summary}

The office space market in Poznan is very volatile, which is characteristic for the initial development stage. Special relation between demand and supply (changes in demand are visible several months later than in supply) has its consequences for investors. Imbalance in supply-demand relation, not only in terms of quantity but mainly of quality, is a frequent phenomenon on the office space market. The partial results of the study presented in the article allow to draw conclusions concerning the criteria applied by tenants when selecting office space. The results may be regarded as guidelines for developers designing office properties. In the period of global economic crisis, tenants often take into account criteria reducing business operating costs rather than the criteria of prestige and location of office properties.

\section{References}

Budner, W. (2004), Lokalizacja przedsiębiorstw. Aspekty ekonomiczno-przestrzenne $i$ środowiskowe, Akademia Ekonomiczna, Poznań.

Celka, K. (2010), Stan i perspektywy rozwoju rynku nieruchomości biurowych $w$ Poznaniu, Świat Nieruchomości, no. 72, Kraków.

Dolf de Roos (2008), Commercial real estate investing, John Wiley \& Sons, New Jersey.

Gawron, H. (2011), Tendencies and forecast of the Polish property market development research possibilities and directions, Zeszyty Naukowe 188, Wydawnictwo UE w Poznaniu, Poznań.

Jaroszewska, E. Stryjakiewicz, T. (2009), Lokalizacja obiektów biurowych $w$ Poznaniu, Bogucki Wydawnictwo Naukowe, Poznań.

Kucharska-Stasiak, E. (2006), Nieruchomość w gospodarce rynkowej, Wyd. Naukowe PWN, Warszawa.

Kyle, R., Baird, F., Spodek, M. (2000), Property management, Dearborn Financial Publishing, Chicago.

Załęczna, M. (2010), Instytucjonalne uwarunkowania rozwoju rynku nieruchomości w Polsce na tle państw zachodnich, Wydawnictwo UŁ, Łódź. 